\title{
Control of the chickpea blight, Ascochyta rabiei, with the weed plant, Withania somnifera
}

\author{
Arshad Javaid ${ }^{*}$, Rukhshanda Munir, Iqra Haider Khan and Amna Shoaib
}

\begin{abstract}
Background: Ascochyta blight caused by a fungal pathogen, Ascochyta rabiei, is a serious disease of chickpea in most chickpea growing areas of the world. The disease can be controlled by fungicides to reduce the environmental pollution.

Main body: This study reports the control of Ascochyta blight by using extracts and dry biomass of a weed plant, Withania somnifera (Family Solanaceae). In a laboratory bioassay, a $0.2 \%$ concentration of methanolic leaf extract of $W$. somnifera significantly inhibited the pathogenic fungal growth. Methanolic leaf extract was fractionated with 4 organic solvents of different polarities namely $n$-hexane, chloroform, ethyl acetate, and $n$-butanol. The effect of different concentrations $\left(3.125,6.25,12.5,25,50,100,200 \mathrm{mg} \mathrm{ml}^{-1}\right)$ of the 4 organic solvent fractions was assessed on in vitro growth of the pathogen. Among these, ethyl acetate and $n$-butanol fractions completely inhibited the fungal growth. Ethyl acetate fraction was further subjected to thin layer chromatography to separate the potent antifungal compounds $\mathrm{A}$ and $\mathrm{B}$. Compound $\mathrm{A}$ was found highly effective against the targeted fungal pathogen with MIC $31.25 \mathrm{\mu g} \mathrm{ml}^{-1}$, followed by B with MIC value of $250 \mathrm{\mu g} \mathrm{ml}^{-1}$ as compared to $7.81 \mathrm{\mu g} \mathrm{ml}^{-1}$ MIC of a commercial fungicide mancozeb. In pot trial, the soil was amended by 1, 2, and $3 \%$ dry leaf material of the test plant species. Disease incidence was significantly reduced in 3\% dose.
\end{abstract}

Conclusions: This study concludes that $W$. somnifera contains potent antifungal compounds that can be effectively exploited for the control of A. rabiei.

Keywords: Ascochyta rabiei, Bioassays guided fractionation, Cicer ariatinum, Withania somnifera

\section{Background}

Chickpea is an excellent drought-tolerant grain legume (Merga and Haji 2019). It plays a vital role in fulfilling the nitrogen requirement through symbiotic $\mathrm{N}_{2}$ fixation and increasing soil fertility (Girma et al. 2017). Ascochyta rabiei is considered a very devastating fungal pathogen responsible for Ascochyta blight to chickpea (Deokar et al. 2019). The disease starts from distal plant portion which may result in wilting with eventual death of the infected plant (Mahmood et al. 2019). The diseased plant shows

\footnotetext{
*Correspondence: arshad.iags@pu.edu.pk; arshadjpk@yahoo.com Institute of Agricultural Sciences, University of the Punjab, Lahore, Pakistan
}

dark brown to black lesions of variable sizes on pods, seeds, branches, stem, leaflets, and stalk.

The pathogen remains viable for more than 2 years on infected seeds and crop residue (Kaiser 1981). It can be effectively managed through chemical practices such as seed and foliar applications of synthetic fungicides (Namriboi et al. 2018). However, due to ill effects of fungicides on environment, use of natural plant-based products against this pathogen is being explored (Shuping and Eloff 2017). Many of the plants are rich in secondary metabolites that have inhibitory effects against the fungal pathogens (Bottger et al. 2018; Akhtar et al. 2020; Javaid et al. 2020). Moreover, the exploitation of phytochemicals is safe,

\section{Springer Open}

(c) The Author(s). 2020 Open Access This article is licensed under a Creative Commons Attribution 4.0 International License, which permits use, sharing, adaptation, distribution and reproduction in any medium or format, as long as you give appropriate credit to the original author(s) and the source, provide a link to the Creative Commons licence, and indicate if changes were made. The images or other third party material in this article are included in the article's Creative Commons licence, unless indicated otherwise in a credit line to the material. If material is not included in the article's Creative Commons licence and your intended use is not permitted by statutory regulation or exceeds the permitted use, you will need to obtain permission directly from the copyright holder. To view a copy of this licence, visit http://creativecommons.org/licenses/by/4.0/. 
eco-friendly, and economical in use when compared to fungicides (Palanichamy et al. 2018).

Withania somnifera (Family Solanaceae) is an important wild plant being used in folk medicines a thousand years ago (Dhanani et al. 2017). It is a small woody shrub native to Indian subcontinent, Southern Europe, and North Africa (Aslam et al. 2017). It contains interesting chemical constituents' profile that are biologically active such as alkaloids, withanone, withasomniferols AC, steroidal compounds, steroidal lactones, withanolides A-Y, withaferin A, withasomniferin-A, and withasomidienone (Tiruveedi et al. 2018). This plant has been studied widely to explore antifungal, antibacterial, antimicrobial, pharmaceutical, antioxidant, and antiinflammatory properties (Shuaib et al. 2019). Previous studies have shown that many members of family Solanaceae exhibited antifungal activities against various fungal plant pathogens (Nino et al. 2006). However, studies regarding the use of $W$. somnifera against $A$. rabiei are lacking. Therefore, the present study was carried out to evaluate the activity of leaf extract and dry biomass of $W$. somnifera for in vitro and in vivo control of A. rabiei.

\section{Materials and methods}

\section{Isolation of the fungal pathogen}

Chickpea pods infected with Ascochyta blight were dried and surface-treated with $1 \%$ sodium hypochlorite solution for $1 \mathrm{~min}$ and sterile water for $1 \mathrm{~min}$. The diseased samples were cut into small pieces and placed on potato dextrose agar (PDA)-containing Petri dishes supplemented with chloromycetin $\left(0.5 \mathrm{~g} \mathrm{l}^{-1}\right)$ and chickpea flour $\left(10 \mathrm{gl}^{-1}\right)$ and incubated at $24^{\circ} \mathrm{C}$ for 2 weeks (Bahr et al. 2016). The growing fungus was subcultured on PDA and was identified based on its phenotypic characters (Aveskamp et al. 2010).

\section{Bioassay-guided fractionation}

Leaves of $W$. somnifera were collected from Lahore, Pakistan, washed and air dried. Dried leaf material $(2 \mathrm{~kg})$ was dipped in methanol (7.0 l) for 10 days, followed by a filtration procedure. The filtrate was evaporated on a rotary evaporator in order to get a concentrated gummy extract. After that, $2.4 \mathrm{~g}$ of the concentrated extract was mixed with autoclaved distilled water to prepare $3 \mathrm{ml}$ of a stock solution. Five concentrations, viz., 0.2, 0.4, 0.6, 0.8 , and $1.0 \mathrm{~g}, 100 \mathrm{ml}^{-1}$ were prepared by addition of 0.2 , $0.4,0.6,0.8$, and $1.0 \mathrm{ml}$ stock solution and $0.8,0.6,0.4$, 0.2 , and $0 \mathrm{ml}$ autoclaved $\mathrm{d} . \mathrm{H}_{2} \mathrm{O}$, respectively, in each $100-\mathrm{ml}$ conical flask and raised the volume up to $80 \mathrm{ml}$ by adding malt extract (ME) broth and divided into 4 equal aliquots. Similarly, a control set was also prepared without addition of plant extract. Actively growing $A$. rabiei culture mycelial plugs (diameter $5 \mathrm{~mm}$ ) were added aseptically in all the conical flasks and kept for 10 days at $18 \pm 2{ }^{\circ} \mathrm{C}$. After that, fungal mats from each flask were harvested, dried, and weighed (Iqbal and Javaid 2012).

Three hundred milliliters of autoclaved $\mathrm{d}_{\mathrm{H}} \mathrm{O}$ ) was mixed with $247 \mathrm{~g}$ of methanolic leaf extract, followed by a partitioning process with $n$-hexane $(2 \times 500 \mathrm{ml})$, chloroform $(600 \mathrm{ml})$, ethyl acetate $(400 \mathrm{ml})$, and $n$-buta$\mathrm{nol}(300 \mathrm{ml})$ in a separating funnel; then, the solvents on a rotary evaporator were evaporated. Each of the extract fractions $(1.2 \mathrm{~g})$ was dissolved in dimethyl sulfoxide (1 $\mathrm{ml}$ ) and raised volume up to $6 \mathrm{ml}$ with the addition of ME broth to make a stock solution. Different concentrations $200,100,50,25,12.5,6.25$, and $3.125 \mathrm{mg} \mathrm{ml}^{-1}$ were formed by a serial double dilution with 3 replicates each. A control solution was also prepared in a similar way by adding $1 \mathrm{ml}$ of dimethyl sulfoxide (DMSO) and ME broth $(5 \mathrm{ml})$. A. rabiei conidial suspension $(20 \mu \mathrm{l})$ was added to each test tube and left for 10 days at $18 \pm 2{ }^{\circ} \mathrm{C}$. Then, the fungal mats from each test tube were harvested, dried, and weighed (Khan and Javaid 2020).

Thin layer chromatography (TLC) was performed by the ethyl acetate fraction, followed by a preparative TLC for the separation of the volatile organic antifungal compounds. The solvent system used for TLC was comprised of $n$-hexane and ethyl acetate in 3:2 ratio. Compounds A and B were separated from the tested fraction with 0.763 and $0.842 R_{\mathrm{f}}$ values, respectively. Both the isolated compounds and mancozeb were used against the pathogen to evaluate the MIC values. For this, mancozeb and the compounds $(8 \mathrm{mg})$ were dissolved in DMSO $(0.25 \mathrm{ml})$ with subsequent addition of ME broth $(1.75 \mathrm{ml})$ serving as a stock solution. Further concentrations, viz., 2000, 1000, 500, 250, 125, 62.5, $31.25,15.62$, and $7.81 \mu \mathrm{g} \mathrm{ml}^{-1}$, were formed from the stock solution of $4000 \mu \mathrm{g} \mathrm{ml}^{-1}$ by serial double dilutions. A control was also prepared simultaneously by adding DMSO $(0.25 \mathrm{ml})$ and ME broth $(1.75 \mathrm{ml})$ with 3 replicates of each. One drop of $A$. rabiei conidial suspension was added in each glass tube. After $72 \mathrm{~h}$, data regarding MIC was recorded by visual determination of the fungal mycelial growth.

\section{Pot trial}

The in vivo study was carried out in plastic pots of $10-\mathrm{cm}$ deep inside, filled with sandy loam soil at $350 \mathrm{~g} \mathrm{pot}^{-1}$. Each pot soil was inoculated by $A$. rabiei inoculum ( $5 \mathrm{~g}$ ) prepared on boiled chickpea seeds and left for 7 days for the establishment of the pathogen. The soil was amended with 3 different concentrations of 1,2 , and $3 \%(\mathrm{w} / \mathrm{w})$ dry leaf biomass of $W$. somnifera. Negative control was prepared by adding sterile boiled chickpea seeds $\left(5 \mathrm{~g} \mathrm{pot}^{-1}\right)$, whereas the positive control was only inoculated by the fungal inoculum $\left(5 \mathrm{~g} \mathrm{pot}^{-1}\right)$ with 10 replicates/treatment. Three surfacesterilized chickpea seeds in sodium hypochlorite solution 
(1\%) were sown in each pot and watered on regular basis. Data regarding disease incidence and shoot and root growth were recorded after 10 weeks of seed sowing. Disease incidence was calculated by the following formula (Javaid and Iqbal 2014):

$$
\text { Disease incidence }(\%)=\frac{\text { No.of diseased plants }}{\text { Total number of plants }}
$$

\section{Statistical analysis}

Experimental data were analyzed by ANOVA, and the treatment means were separated by Duncan's multiple range test using software COSTAT at $P \leq 0.05$.

\section{Results and discussion} In vitro bioassay

$W$. somnifera leaf extract proved to be extremely effective in inhibiting the growth of chickpea blight pathogen. Different concentrations markedly reduced the fungal biomass by $33-43 \%$ as shown in Fig. 1. Earlier, Nefzi et al. (2016) studied the antifungal effects of aqueous and organic solvent extract of various parts of W. somnifera and reported that a 3\% aqueous leaf extract reduced growth of Fusarium oxysporum f. sp. radicis-lycopersici by $45 \%$. A $200 \mathrm{mg} \mathrm{ml}^{-1}$ concentration of $n$-butanol fraction of methanolic leaf extract of this plant also significantly reduced growth of $F$. oxysporum $\mathrm{f}$. sp. cepae (Akhtar and Javaid 2018). Aqueous and methanolic extracts of leaves and other parts of this plant have been also reported to have pronounced antifungal activity against a number of fungal species namely: Candida albicans, Curvularia lunata and Alternaria alternata, A. brassicae, A. solani, and Phytophthora infestans. Extracts

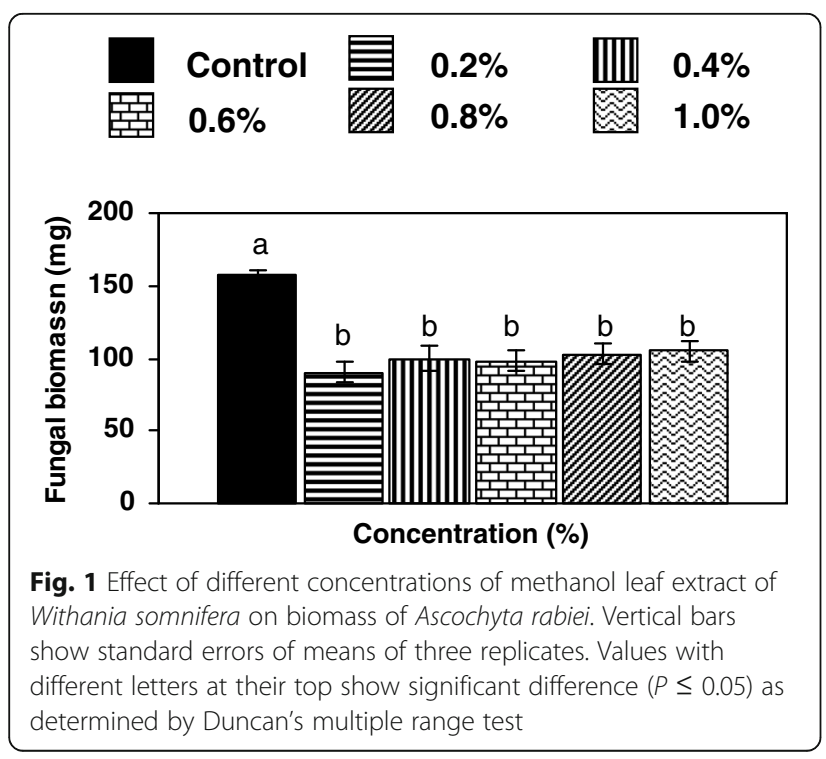

of W. somnifera had the ability to suppress germination of spores/conidia as well as to arrest the mycelial growth (Baka 2010 and Sailaja 2014). Antifungal activity of W. somnifera is related to various alkaloids and steroidal lactones (Singh et al. 2010). There are also many previous reports, where A. rabiei showed susceptibility to many other plant extracts. Yilar and Bayar (2019) reported an antifungal potential of Salvia tomentosa and $S$. officinalis extracts against $A$. rabiei isolates. Likewise, Amin et al. (2012) demonstrated that the bark and stem methanolic extracts of Eucalyptus citriodora also had antifungal efficacy against this pathogen. Similarly, Ghazanfar et al. (2011) worked on different plant leaf extracts, viz., Allium sativum, Azadirachta indica, and Datura metel, against $A$. rabiei and found that $A$. indica extract was highly antifungal against the pathogen. Moreover, Onaran (2016) tested different plant extracts namely: Heracleum platytaenium, Vitex agnus-castus, Ricinus communis, Polygonum cognatum, and Isatis glauca prepared in different organic solvents and found all the extracts highly inhibitory against the mycelial growth of the pathogen. $R$. communis extract caused $100 \%$ control of the pathogen.

The highest and the second highest concentrations of DMSO in control solution adversely effected the pathogen growth with 100\% inhibition. Therefore, these 2 concentrations were not considered in cases of the 2 highest concentrations (100 and $200 \mathrm{mg} \mathrm{ml}^{-1}$ ) of different fractions of leaf extract. The lowest concentrations of $n$-hexane fraction reduced the fungal biomass by $75-89 \%$, and the highest concentration $\left(50 \mathrm{mg} \mathrm{ml}^{-1}\right)$ arrested the pathogen growth by $99 \%$. High concentrations of chloroform fraction, viz., $12.5,25$, and $50 \mathrm{mg} \mathrm{ml}^{-1}$, completely retarded the pathogenic growth, while its low concentration of 3.12 and $6.25 \mathrm{mg} \mathrm{ml}^{-1}$ reduced pathogen biomass by 74 and $77 \%$, respectively. The other 2 fractions, namely, $n$-butanol and ethyl acetate, were the most antifungal, where all the concentrations completely controlled the pathogen growth. Different concentrations of aqueous fraction, viz., $50,25,12.25,6.25$, and $3.12 \mathrm{mg} \mathrm{ml}^{-1}$, stimulated the growth of the pathogen by $81,52,48,63$, and $22 \%$, respectively (Table 1 ). In the present study, leaf methanolic extract was fractionated by using a variety of organic solvents each having different polarity. This process separated compounds of methanolic extract into different groups depending upon polarity nature of organic solvents. Different organic fractions showed variable antifungal activities when bioassays were carried out against $A$. rabiei. Among these, the most polar organic fractions, viz., $n$-butanol and ethyl acetate, were very effective in reducing the pathogen growth. Both the fractions were effective at very low concentration, i.e., $3.125 \mathrm{mg} \mathrm{ml}^{-1}$. Chloroform fraction with MIC of $12.5 \mathrm{mg} \mathrm{ml}^{-1}$ was moderately effective. None of the applied concentrations of the 
Table 1 Effect of different concentrations of $n$-hexane, chloroform, ethyl acetate, $n$-butanol, and aqueous fraction of methanolic leaf extract of Withania somnifera against Ascochyta rabiei

\begin{tabular}{|c|c|c|c|}
\hline Methanolic fraction & Conc. of DMSO $\left(\mathrm{ml} \mathrm{ml}^{-1}\right)$ & Extract conc. (mg ml ${ }^{-1}$ ) & Fungal biomass (mg) \\
\hline \multirow[t]{7}{*}{ Control } & 0.1666 & 0 & $0 \mathrm{k}$ \\
\hline & 0.0833 & 0 & $0 k$ \\
\hline & 0.0416 & 0 & $1.1 \mathrm{hi}$ \\
\hline & 0.0208 & 0 & $1.93 \mathrm{~g}$ \\
\hline & 0.0104 & 0 & $2.56 \mathrm{f}$ \\
\hline & 0.0052 & 0 & $3.06 \mathrm{e}$ \\
\hline & 0.0025 & 0 & $4.53 \mathrm{c}$ \\
\hline \multirow[t]{7}{*}{ n-hexane } & 0.1666 & 200 & $0 \mathrm{k}$ \\
\hline & 0.0833 & 100 & $0 \mathrm{k}$ \\
\hline & 0.0416 & 50 & $0.1 \mathrm{k}$ \\
\hline & 0.0208 & 25 & $0.2 \mathrm{k}$ \\
\hline & 0.0104 & 12.5 & $0.5 \mathrm{j}$ \\
\hline & 0.0052 & 6.25 & $0.63 \mathrm{j}$ \\
\hline & 0.0025 & 3.125 & $1.1 \mathrm{i}$ \\
\hline \multirow[t]{7}{*}{ Chloroform } & 0.1666 & 200 & $0 \mathrm{k}$ \\
\hline & 0.0833 & 100 & $0 k$ \\
\hline & 0.0416 & 50 & $0 \mathrm{k}$ \\
\hline & 0.0208 & 25 & $0 \mathrm{k}$ \\
\hline & 0.0104 & 12.5 & $0 k$ \\
\hline & 0.0052 & 6.25 & $0.7 \mathrm{j}$ \\
\hline & 0.0025 & 3.125 & $1.16 \mathrm{hi}$ \\
\hline \multirow[t]{7}{*}{ Ethyl acetate } & 0.1666 & 200 & $0 \mathrm{k}$ \\
\hline & 0.0833 & 100 & $0 k$ \\
\hline & 0.0416 & 50 & $0 \mathrm{k}$ \\
\hline & 0.0208 & 25 & $0 \mathrm{k}$ \\
\hline & 0.0104 & 12.5 & $0 \mathrm{k}$ \\
\hline & 0.0052 & 6.25 & $0 \mathrm{k}$ \\
\hline & 0.0025 & 3.125 & $0 \mathrm{k}$ \\
\hline \multirow[t]{7}{*}{ n-butanol } & 0.1666 & 200 & $0 \mathrm{k}$ \\
\hline & 0.0833 & 100 & $0 \mathrm{k}$ \\
\hline & 0.0416 & 50 & $0 \mathrm{k}$ \\
\hline & 0.0208 & 25 & $0 \mathrm{k}$ \\
\hline & 0.0104 & 12.5 & $0 \mathrm{k}$ \\
\hline & 0.0052 & 6.25 & $0 \mathrm{k}$ \\
\hline & 0.0025 & 3.125 & $0 \mathrm{k}$ \\
\hline \multirow[t]{7}{*}{ Aqueous } & 0.1666 & 200 & $0 \mathrm{k}$ \\
\hline & 0.0833 & 100 & $1.3 \mathrm{~h}$ \\
\hline & 0.0416 & 50 & $2 \mathrm{~g}$ \\
\hline & 0.0208 & 25 & $2.93 \mathrm{e}$ \\
\hline & 0.0104 & 12.5 & $3.8 \mathrm{~d}$ \\
\hline & 0.0052 & 6.25 & $5 b$ \\
\hline & 0.0025 & 3.125 & $5.56 \mathrm{a}$ \\
\hline
\end{tabular}


non-polar $n$-hexane fraction completely controlled the fungal growth. Similar variability was also observed in antifungal activities of different fractions of Coronopus didymus leaf extract against Sclerotium rolfsii (Iqbal and Javaid 2012), leaf extract of Datura metel against Macrophomina phaseolina (Javaid and Saddique 2012), radish extract against Fusarium oxysporum (Javaid and Bashir 2015), and Nigella sativa extract against M. phaseolina and F. oxysporum (Aftab et al. 2019).

Mancozeb was highly effective, suppressed the fungal growth with $7.81 \mu \mathrm{g} \mathrm{ml}^{-1}$ MIC. The two compounds of ethyl acetate fraction were less effective against $A$. rabiei than mencozeb. Compound A exhibited better results in inhibiting the growth of fungal pathogen with the minimum inhibitory concentration of $31.25 \mathrm{\mu g} \mathrm{m}^{-1}$. Compound B was less toxic with MIC $250 \mu \mathrm{g} \mathrm{ml}^{-1}$ (Table 2). A variety of low molecular weight secondary metabolites was reported in $W$. somnifera including withanolides, tannins, alkaloids, flavonoids, terpenoids, and resins (Dahr et al. 2015). Free and bound flavonoids of this plant suppressed the growth of C. albicans (Singh and Kumar 2011). Ghosh (2009) isolated a $30 \mathrm{kDa}$ monomeric acidic lectin-like protein from leaves of W. somnifera and found it as effective against fungi as standard lectins.

In vertical column, values with different letters show significant difference $(p \leq 0.05)$ as determined by Duncan's multiple range test

\section{Pot trial}

Data regarding the effect of dry leaf biomass of $W$. somnifera (LBW) on germination of chickpea seeds in $A$. rabiei-inoculated soil is presented in Fig. 2a. The negative control showed the highest germination of $68 \%$, where the pot soil was non-amended and seeds were sown in non-inoculated soil. In positive control, seeds were sown in A. rabiei-inoculated pots, and the lowest germination (18\%) was recorded in this treatment. Different doses of LBW enhanced the germination of chickpea seeds over positive control. Different doses of LBW evidently effected the germination of test plant as 33,34 , and $50 \%$ germination was noted in 1, 2, and $3 \%$ doses, respectively. Positive control showed the highest disease incidence by $66 \%$ whereas disease incidence was recorded as 38,40 , and $28 \%$ in 1,2 , and $3 \%$ LBW, respectively (Fig. 2b). The highest values of dry shoot and root biomasses of chickpea were noted in the negative control treatment and the lowest in the positive control treatment with significant difference between the two. Both shoot and root dry biomasses were gradually increased as the dose of LBW was increased from 1 to $3 \%$. The increase in shoot and root biomasses due to different doses of LBW was 116-283 and 66-333\% over positive control, respectively (Fig. 3).

In pot trial, application of different doses of dry leaf biomass of $W$. somnifera variably controlled disease and improved germination and crop growth. The lowest disease incidence and the highest positive effects on germination and seedling growth were recorded in 3\% dose of leaf biomass. These findings are in conformity with previous investigation that documented stimulatory action of soil amendments using leaf biomass of $W$. somnifera on growth of onion plant along with suppression in Fusarium wilt disease (Akhtar and Javaid 2018). Observed enhancement in growth of chickpea along with management of the disease may be ascribed to occurrence of many biological active compounds, mainly alkaloids (isopelletierine, anaferine) and steroids (withanolides, withaferins) in leaves of W. somnifera (Pandey et al. 2018). These might have influenced host plant physiological responses triggered by signal transduction process that may lead to extensive cross-talk between pathways to accumulate defense-related compounds upon encountering disease stresses (Isah 2019).

\section{Conclusion}

This study concludes that the leaf extract of W. somnifera was very effective in controlling the growth of $A$. rabiei. Antifungal constituents were mostly present in the 2 polar solvent fractions, viz., ethyl acetate and $n$-butanol. Soil application of dry biomass of $W$. somnifera at $3 \% \mathrm{w} / \mathrm{w}$ concentration had the ability to significantly reduce disease incidence and to improve germination and plant growth in A. rabiei-contaminated soil.

Table 2 Antifungal activity of isolated compounds against Ascochyta rabiei

\begin{tabular}{|c|c|c|c|c|c|c|c|c|c|c|}
\hline \multirow[t]{2}{*}{ Treatments } & \multicolumn{10}{|c|}{ Concentrations $\mu \mathrm{g} \mathrm{ml}^{-1}$} \\
\hline & 4000 & 2000 & 1000 & 500 & 250 & 125 & 62.5 & 31.25 & 15.62 & 7.81 \\
\hline${ }^{\mathrm{a} C o n t r o l}$ & + & + & + & + & + & + & + & + & + & + \\
\hline Mencozeb & - & - & - & - & - & - & - & - & - & - \\
\hline Compound A & - & - & - & - & - & - & - & - & + & + \\
\hline Compound B & - & - & - & - & - & + & + & + & + & + \\
\hline
\end{tabular}

+ Fungal growth appears

- No fungal growth

${ }^{a}$ Concentrations are only for compounds A-D and mencozeb 

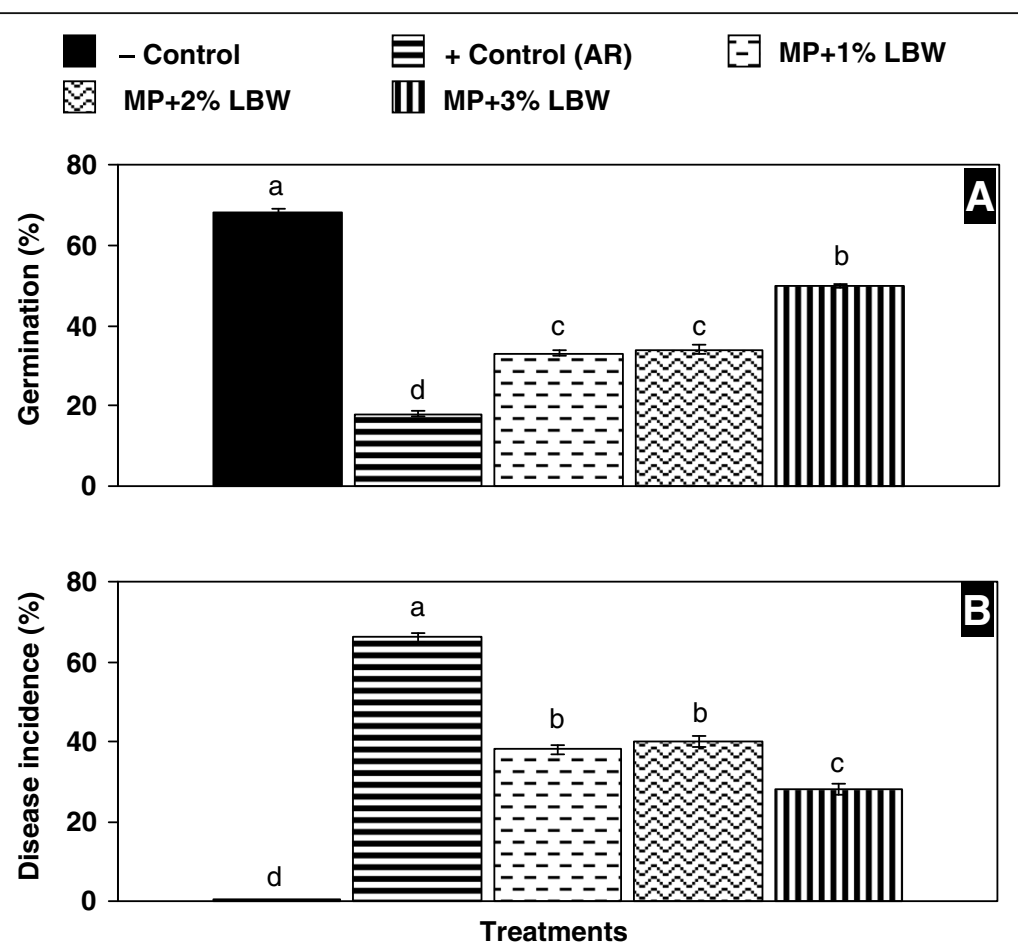

Fig. 2 Effect of Ascochyta rabiei inoculation and different concentrations of dry leaf manure of Withania somnifera (LBW) on germination of chickpea seeds and disease incidence. Vertical bars show standard errors of means of three replicates. Values with different letters at their top show significant difference $(P \leq 0.05)$ as determined by Duncan's multiple range test

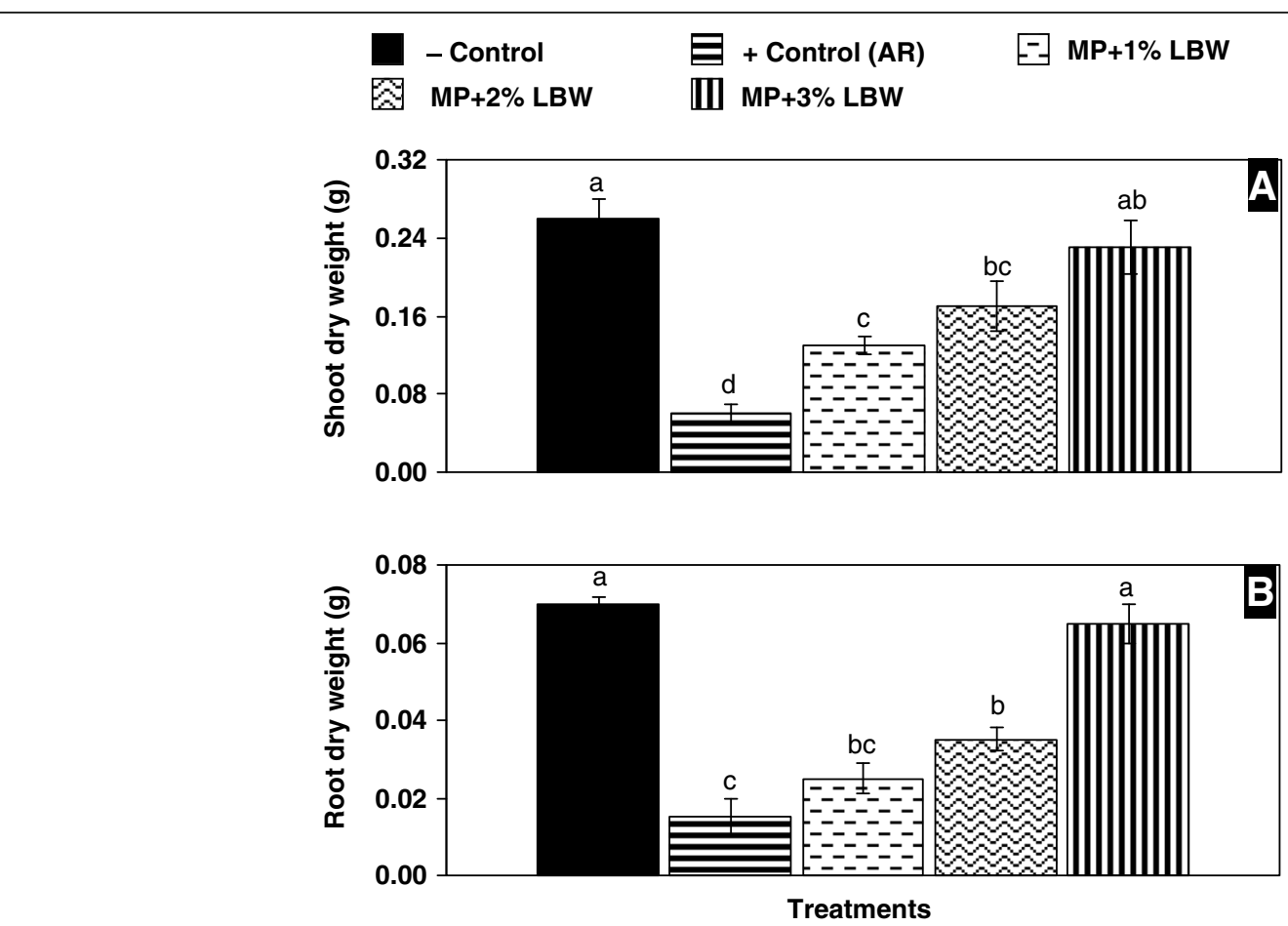

Fig. 3 Effect of Ascochyta rabiei inoculation and different concentrations of dry leaf manure of Withania somnifera on shoot and root growth of chickpea. Vertical bars show standard errors of means of three replicates. Values with different letters at their top show significant difference $(P \leq$ 0.05) as determined by Duncan's multiple range test 


\section{Abbreviations}

ME: Malt extract; ANOVA: Analysis of variance; LBW: Leaf biomass of $W$. somnifera; TLC: Thin layer chromatography; MIC: Minimum inhibitory concentration

\section{Acknowledgements \\ Not applicable}

\section{Authors' contributions}

RM conducted the study. AJ supervised the work, analyzed the data, and approved the final manuscript. IHK and AS contributed in paper writing. All authors have read and approved the manuscript

\section{Funding}

Not applicable

\section{Availability of data and materials}

The datasets used and/or analyzed during the current study are available from the corresponding author on reasonable request.

\section{Ethics approval and consent to participate}

Not applicable

\section{Consent for publication}

All authors are agreed to publish this paper.

\section{Competing interests}

The authors declare that they have no competing interests.

\section{Received: 6 July 2020 Accepted: 31 August 2020}

Published online: 14 September 2020

\section{References}

Aftab A, Yousaf Y, Javaid A, Riaz N, Younas A, Rashid M, Shamsher B, Arif A (2019) Antifungal activity of vegetative methanolic extracts of Nigella sativa L. against Fusarium oxysporum and Macrophomina phaseolina and its phytochemical profiling by GC-MS analysis. Int J Agric Biol 21:569576

Akhtar R, Javaid A (2018) Biological management of basal rot of onion by Trichoderma harzianum and Withania somnifera. Planta Daninha 36 e017170507

Akhtar R, Javaid A, Qureshi MZ (2020) Efficacy of shoot extracts of Sisymbrium irio against Fusarium oxysporum f. sp. cepae. Planta Daninha 38:e020200961

Amin M, Javaid A, Athar MM (2012) Prospects of using fruit and bark extracts of Eucalyptus citriodora for control of Ascochyta rabiei, the causal organism of chickpea blight. Mycopath 10:51-55

Aslam S, Raja NI, Hussain M, Iabal M, Ejaz M, Ashfaq D, Ehsan M (2017) Current status of Withania somnifera (L.) Dunal: an endangered medicinal plant from Himalaya. Am J Plant Sci 8:1159-1169

Aveskamp MM, Gruyter D, Woudenberg JHC, Verkey GJM, Crous PW (2010) Highlights of the Didymellaceae: a poliphasic approach to characterize Phoma and related pleosporalean genera. Stud Mycol 65:1-60

Bahr L, Castelli MV, Barolo MA, Mostacero NR, Tosello ME, Lopez SN (2016) Ascochyta blight: isolation, characterization, and development of a rapid method to detect inhibitors of the chickpea fungal pathogen Ascochyta rabiei. Fungal Biol 120:424-432

Baka ZAM (2010) Antifungal activity of six Saudi medicinal plant extracts against five phyopathogenic fungi. Arch Phytopathol Plant Prot 43:736-743

Bottger A, Vothknecht U, Bolle C, Wolf A (2018) Secondary metabolites in plants: general introduction. In: Lessons on caffeine, cannabis \& Co. Springer, Cham, pp 143-152

Dahr N, Razdan S, Rana S, Bhat WW, Vishwakarma R, Lattoo SK (2015) A decade of molecular understanding of withanolide biosynthesis and in vitro studies in Withania somnifera (L.) Dunal: prospects and perspectives for pathway engineering. Front. Plant Sci 6:1031

Deokar A, Sagi M, Daba K, Tar'an B (2019) QTL sequencing strategy to map genomic regions associated with resistance to Ascochyta blight in chickpea. Plant Biotechnol J 17:275-288
Dhanani T, Shah S, Gajbhiye NA, Kumar S (2017) Effect of extraction methods on yield, phytochemical constituents and antioxidant activity of Withania somnifera. Arab J Chem 10:1193-1199

Ghazanfar MU, Wakil W, Sahi ST (2011) Induction of resistance in chickpea (Cicer arietinum L.) against Ascochyta rabiei by applying chemicals and plant extracts. Chil J Agric Res 71:52-62

Ghosh M (2009) Purification of a lectin-like antifungal protein from the medicinal herb, Withania somnifera. Fitoterapia 80:91-95

Girma N, Mekibib F, Fikre A, Keneni G, Nvpr GR, Gaur P, Ojiewo CO (2017) Heterosis for nitrogen fixation and seed yield and yield components in chickpea (Cicer arietinum L.). Int J Sustain Agric Res 4:50-57

labal D, Javaid A (2012) Bioassays guided fractionation of Coronopus didymus for its antifungal activity against Sclerotium rolfsii. Nat Prod Res 26:16381644

Isah T (2019) Stress and defense responses in plant secondary metabolites production. Biol Res 52:39

Javaid A, Afzal R, Shoaib A (2020) Biological management of southern blight of chili by Penicillium oxalicum and leaves of Eucalyptus citriodora. Int J Agric Biol 23:93-102

Javaid A, Bashir A (2015) Radish extracts as natural fungicides for management of Fusarium oxysporum f. sp. lycopersici, the cause of tomato wilt. Pak J Bot 47(SI):321-324

Javaid A, labal D (2014) Management of collar rot of bell pepper (Capsicum annuum L.) by extracts and dry biomass of Coronopus didymus shoot. Biol Agric Hort 30(3):164-172

Javaid A, Saddique A (2012) Control of charcoal rot fungus Macrophomina phaseolina by extracts of Datura metel. Nat Prod Res 26:1715-1720

Kaiser WJ (1981) Control of ascochyta blight of chickpea through clean seed. In: Proc of the workshop on Ascochyta blight and winter sowing of chickpeas. ICARDA, Aleppo, pp 4-7

Khan $1 \mathrm{H}$, Javaid A (2020) Comparative antifungal potential of stem extracts of four quinoa varieties against Macrophomina phaseolina. Int J Agric Biol 24: 441-446

Mahmood MT, Ahmad M, Ali I (2019) Chickpea blight: former efforts on pathogenicity, resistant germplasm and disease management. Gomal Univ J Res 35:1-10

Merga B, Haji J (2019) Economic importance of chickpea: production, value, and world trade. Cogent Food Agric 5:1615718

Namriboi BK, Devi RT, Majumder D, Thakur NA, Hemochandra L (2018) Efficacy of plant extracts and chemicals against Ascochyta phaseolorum, causal agent of ascochyta blight of Vigna anguiculata (L.) Walp. Int J Curr Microbiol Appl Sci 7:403-412

Nefzi A, Abdallah RAB, Jabnoun-Khiareddine H, Medimagh-Saïdana S, Haouala R, Daami-Remadi M (2016) Antifungal activity of aqueous and organic extracts from Withania somnifera L. against Fusarium oxysporum f. sp. radicislycopersici. J Microb Biochem Technol 8:3

Nino J, Correa YM, Mosquera OM (2006) Antibacterial, antifungal, and cytotoxic activities of 11 Solanaceae plants from Colombian biodiversity. Pharmaceut Biol. 44:14-18

Onaran A (2016) In vitro antifungal activities of some plant extracts against plant pathogenic fungi in Turkey. Egypt J Biol Pest Control 26:111-114

Palanichamy P, Krishnamoorthy G, Kannan S, Marudhamuthu M (2018) Bioactive potential of secondary metabolites derived from medicinal plant endophytes. Egypt J Basic Appl Sci 5:303-312

Pandey A, Bani S, Dutt P, Satti NK, Suri KA, Qazi GN (2018) Multifunctional neuroprotective effect of Withanone, a compound from Withania somnifera roots in alleviating cognitive dysfunction. Cytokine 102:211-221

Sailaja I (2014) Antifungal activity of some wild plant extracts against fungal pathogens. Int J Intg Med Sci 1:41-44

Shuaib M, Ali S, Ali K, Hussain F, Ilyas M, Arif M, Hussain F (2019) Validation of the ethnopharmacological uses of Withania somnifera. Int J Nanotechnol Allied Sci 3:1-6

Shuping DSS, Eloff JN (2017) The use of plants to protect plants and food against fungal pathogens: a review. Afr J Trad Complement Altern Med 14:120-127

Singh AP, Tanwr BS, Khan M (2010) Antifungal potential of Ashwagandha against some pathogenic fungi. Int J Biopharmaceut 1:72-74

Singh G, Kumar P (2011) Evaluation of antimicrobial efficacy of flavonoids of Withania Somnifera L. Indian J Pharm Sci 73:473-478 
Tiruveedi VL, Bale S, Khurana A, Godugu C (2018) Withaferin A, a novel compound of Indian ginseng (Withania somnifera), ameliorates C erulein induced acute pancreatitis: possible role of oxidative stress and inflammation. Phytother Res 32:2586-2596

Yilar M, Bayar Y (2019) Antifungal potential of essential oils of Salvia officinalis and Salvia tomentosa plants on six different isolates of Ascochyta rabiei (Pass.) Lab. Fresenius Environ Bull 28:2170-2175

\section{Publisher's Note}

Springer Nature remains neutral with regard to jurisdictional claims in published maps and institutional affiliations.

Submit your manuscript to a SpringerOpen ${ }^{\circ}$ journal and benefit from:

- Convenient online submission

- Rigorous peer review

- Open access: articles freely available online

- High visibility within the field

- Retaining the copyright to your article

Submit your next manuscript at $\boldsymbol{\sim}$ springeropen.com 